\title{
Why early collective action pays off: evidence from setting Protected Geographical Indications
}

\author{
Xiomara F. Quiñones-Ruiz ${ }^{1 *}$, Marianne Penker ${ }^{1}$, Giovanni Belletti ${ }^{2}$, Andrea Marescotti ${ }^{2}$ and \\ Silvia Scaramuzzi \\ 'Department of Economics and Social Sciences, University of Natural Resources and Life Sciences, Vienna \\ (BOKU), Austria. \\ 'Dipartimento di Scienze per l'Economia e l'Impresa, Università di Firenze. \\ ${ }^{*}$ Corresponding author: xiomara.fernanda.quinones-ruiz@boku.ac.at
}

Accepted 4 April 2016; First published online 22 June 2016

Research Paper

\begin{abstract}
The registration of Geographical Indications (GIs) under the European Union (EU) legislation requires collective action and considerable efforts borne by multiple actors such as producers, processors, public authorities and research centers. We analyze their efforts, risks and benefits by comparing two EU GI registration processes in Italy and Austria, namely the Sorana bean Protected Geographical Indication (PGI) and the Perry from Mostviertel PGI. Results from the institutional and transaction costs analysis suggest that intensive interaction for solving conflicting interests, negotiating quality standards and defining common rules might pay off in indirect benefits and reduced risks. In particular, an inclusion of diverse and heterogeneous interest groups and a high degree of direct enterprise participation along the GI application process (as observed in the Italian case) generate benefits such as trust and social cohesion, which then support the actual use of the GI label and a better implementation of associated quality standards. A supportive legal framework with assistance from public authorities can back up the community of producers not only in technical aspects, but also as mediators when conflicts seem to be difficult to solve. As there seems to be a positive relationship between the intensity and effectiveness of collective action and the likelihood of achieving broadly accepted standards and social cohesion needed for successful GI implementation, the question for future research would not be how to avoid collective efforts but how to effectively organize the interaction among heterogeneous producer groups.
\end{abstract}

Key words: geographical indication, protected geographical indication, collective action, registration, efforts, benefits, risks, EU

\section{Introduction}

Geographical Indications (GIs) allow producers to define quality standards and defend their food products' reputation, while highlighting their geographical origin, local skills and value to consumers. For the registration of a GI within the European Union (EU) scheme, initially set up by EU Council Regulation 2081/1992 (now Regulation 1151/2012), local producers and processors have to organize and collectively define the area of production, the characteristics of the production process and those of the final product. These common rules are summarized in the so-called Product Specification, which is essential for the application to the EU. Once EU recognition is obtained, GIs in EU territory will be used only for products complying with Product Specification.
Due to heterogeneous interests of producers and processors diverging in size, location and quality standards, mutual agreements (Paus and Reviron, 2010; Galtier et al., 2013) have to be reached. This requires considerable collective efforts on the meso-level (Vandecandelaere et al., 2009). We assume that the interaction of GI enterprises will be shaped by formal and informal institutions (Reviron and Chappuis, 2011; Sidali and Scaramuzzi, 2014). The European legal framework provides the overall regulatory structures for GI registration; however, there is some scope for national specifications (e.g., requirements, procedures and authorities responsible for the national analysis of dossiers). We assume that the way EU states design and organize the national phase of the GI registration process is relevant, e.g., top-down processes often result in low ex-ante efforts and high ex-post efforts, while participatory processes usually have high ex-ante and low ex-post 
efforts (Hanna, 1994, 1995; Jena and Grote, 2010); additionally, very weak cooperation or too centralized management might not be efficiently run collective organizations (Hanna, 1995). Furthermore, efforts made for information gathering and for other forms of interaction can also result in transaction benefits (Hanna, 1995; Enengel et al., 2014) that surpass the efforts made to obtain the GI registration. However, the governance of participatory group processes also bears risks, such as unsolvable conflicts (Hanna, 1994; Enengel et al., 2014; Sidali and Scaramuzzi, 2014).

Reviron and Chappuis (2011) explain the importance of collective organization in the European vision of Protected Geographical Indications (PGI) and Protected Designations of Origin (PDO). However, there is yet very little literature scrutinizing GI registration processes and the institutional mechanisms that shape collective efforts, risks and benefits of this process among the interaction of various supply chain actors (Paus and Reviron, 2010) and institutional diversity (Bowen and Zapata, 2009).

Thus, we aim to get empirical insights on the GI registration processes and the associated efforts, risks and benefits of the producers' collective action. The aims of the paper are:

(1) to identify the types of public and private actors who are involved along GI registration processes in the EU,

(2) to estimate and compare efforts, risks and benefits they perceived during the registration process and

(3) to identify the link between the GI registration process and the success of the GI initiative in terms of GI use by enterprises.

We present the theoretical framework and methods that guide our research in the following section. In the Results section, we illustrate the analysis of the registration processes and the collective efforts, risks and benefits of two cases from Italy and Austria. In the Discussion, we compare and discuss the case studies' results. We end with the Conclusion.

\section{Theoretical framework and methods}

Following the research carried out by Quiñones-Ruiz et al. (2014), the comparative study of the two GI registration processes in Italy and Austria is guided by the Institutional Analysis and Development (IAD) framework (Ostrom et al., 1994; Ostrom, 2005; Hess and Ostrom, 2007) as well as an analytical scheme that structures the analysis of efforts, risks and benefits of participatory processes (North, 1990; Allen, 1991; Penker and Klemen, 2010).

\section{The IAD framework}

GIs and the reputation they incorporate are comparable with common-pool resources (Winfree and McCluskey, 2005; Quiñones-Ruiz et al., 2015), as they refer to natural or human systems that generate limited benefits and are challenged by over-exploitation and free-riding (Ostrom et al., 1994). Collective efforts to build up and sustain product quality, clear rules, considerable monitoring and sanctioning efforts are needed to maintain the GI reputation and to effectively exclude illegitimate users. Producers that are located in the defined GI area and comply with the product specification are allowed to benefit from the reputation of protected GIs (Babcock and Clemens, 2004; Biénabe et al., 2011).

The collective action in diverse GI production systems is shaped by GI firms' own formal and informal rules (e.g., rules of producer organizations, conventions of production) and by the formal legal context, in which the development of a GI takes place. The opportunities or limitations that individuals face in a given situation, the information acquired, the benefits they would accrue or be excluded from and how they rationalize a situation are all affected by the rules or the lack of rules that frame an event (Ostrom, 2005). Ostrom (1990) and Ostrom and Polski (1999) claim that all efforts to organize collective action must address a common set of problems, such as coping with free-riding or monitoring individual compliance with GI rules. As GI enterprises also manage the common reputation of their regional product and protect it from free-riding, we opted for the long-standing IAD framework designed for the institutional analysis of self-organized common-pool resource management (Ostrom et al., 1994; Hess and Ostrom, 2007).

The IAD framework distinguishes key variables that researchers use to assess the role of institutions in shaping human interactions and decision-making processes. Thus, following the IAD framework's variables (Ostrom et al., 1994; Ostrom and Polski, 1999; Hess and Ostrom, 2007) and GI literature, the relevant categories of analysis regarding the contextual and institutional situation include:

(1) The link of the product to the territory (analog to the bio-physical characteristics as defined by Hess and Ostrom 2007). Here, it is necessary to understand the concept of 'terroir' argued by Casabianca et al. (2005). Terroir is defined as a geographical boundary, in which a community has constructed - through history - an intellectual and collective know-how of production, which is based on a system of interactions between a physical and biological environment together with human factors that reveal originality, confer typicality and engender a reputation for a product.

(2) The attributes of the community of producers and other actors involved in the GI production, with a special focus on representative organizations.

(3) The rules in use, including European and national regulative GI frameworks and informal rules (e.g., local customs or social norms on collaboration) 
affecting the stakeholders' interaction in the action arena.

(4) The 'action arena', which is defined as the social place where actors interact, make decisions, solve problems or fight.

(5) The outcome of the GI process (Product Specification setting the quality standards for the EU registration).

The IAD framework's core is the 'action arena' (Ostrom, 2005; Hess and Ostrom, 2007), which-as we assume in this paper-also shapes the allocation of transaction efforts, benefits and risks.

\section{Collective efforts, risks and benefits}

The protection of GIs, similar to agri-environmental schemes or ethical food labeling, requires considerable organizational and bureaucratic efforts. In recent decades, several empirical studies looked at these efforts borne by farmers and by other public and private actors (McCann and Easter, 1997; Falconer and Whitby, 1999; McCann et al., 2005; Mettepenningen and Van Huylenbroeck, 2009; Enengel et al., 2014). These studies refer to transaction cost theory and make special reference to non-market transaction costs. We follow the definition of McCann et al. (2005), in which transaction costs are linked to the resources needed to create and maintain property rights and as dependent on the institutional environment (North, 1990; Allen, 1991).

GI enterprises and other actors involved in GI production systems aiming to register and protect their GI must agree on Product Specification. According to the EU regulation, only a group (of producers and processors) is entitled to apply for registration. Producers normally do not share the same production techniques and have different interests in the GI product. For this reason, the process of convergence is costly, indeed interactions that take place in the action arena ask for considerable effort to be made by individual enterprises, collective associations and public organizations involved in the GI production system. The main elements are time spent in meetings and the time required to acquire information and to communicate with other actors (Penker and Klemen, 2010; Enengel et al., 2011, 2014).

However, along the GI process, some monetary expenses may also occur. They can include consultancy costs (e.g., studies supporting the definition of Product Specification, legal and technical advice), some investments (laboratory analysis for the product characterization) and overheads (phone calls, fuel, trips). The latter can be assumed to be proportional to the time spent; therefore we did not include them in our comparative analysis. Although other expenses may highly affect GI registration costs, they were not relevant in the cases analyzed or transferred into time efforts. For instance, some studies about product characteristics had been carried out before the GI registration process, and some consultancies were free of charge because of the personal involvement of experts. We converted the remaining monetary expenses into working hours, so that all the results could be comparatively presented as time efforts. Taking the collective efforts until GI registration as boundaries of our study, we did not examine production costs before and after registration, efforts to adapt to the GI requirements or certification and transaction costs for GI use after registration (e.g., costs for quality control, court costs).

Ilbery and Kneafsey (2000) cautioned that some GI applicants will most likely be discouraged because of high-bureaucracy hurdles and associated efforts. Transaction costs theory argues that time efforts for information gathering, negotiations and other forms of interaction can result in transaction benefits (McCann et al., 2005). Thus, efforts made in the registration process cannot be assessed without including the benefit side. Besides direct benefits, such as increases in product prices or sales figures, researchers and rural development agents emphasize indirect benefits resulting from the intensified interaction of producers and processors during the registration process. Transaction cost theory provides the conceptual framework to contrast these indirect benefits-or transaction services - with the associated transaction costs.

We analyzed benefits resulting from the intensified interaction of producers, processors and other parties in the GI territory to set up the GI protection, but not the post-registration benefits from the very use of the registered GI. We derived relevant benefit categories from GI literature, e.g., vertical and horizontal integration, higher or better accepted quality standards, social learning processes (Sanz-Cañada and Macias-Vázquez, 2005; Giovannucci et al., 2009, 2010; Reviron and Chappuis, 2011; Coulet, 2012; Bagal et al., 2013; Barjolle, 2016), but we excluded benefits that would result from the actual use of the GI (e.g., price premiums, rural development benefits). In the action arena analysis and as explanatory variable of efforts, we also included risks linked to possible failures of the collective GI registration process (unsolvable conflicts, lack of information, unclear regulation) (Barjolle and Sylvander, 2000; Ilbery and Kneafsey, 2000; Giovannucci et al., 2009, 2010; Coulet, 2012; Rangnekar and Mukhopadhyay, 2016). However, we excluded post-registration risks that affect the GI use (e.g., inadequate consumer knowledge of the GI).

\section{Methods: comparative case study design, data collection and analysis}

Our paper is based on a comparative analysis of two GI case studies. According to Poteete et al. (2010), a case study allows an intensive analysis of a well-bound phenomenon and is the only feasible choice for empirically based research when cross-case data are limited. Case studies identify the main sources of collective efforts, risks and benefits associated with the GI registration process and the involved actors, measure efforts in terms 
Table 1. PGI cases, affiliation and number of interviewees.

\begin{tabular}{|c|c|c|}
\hline & Sorana bean, Italy & Mostviertel perry, Austria \\
\hline GI management & $\begin{array}{l}\text { Il Ghiareto ONLUS Associazione dei Piccoli } \\
\text { Produttori del Fagiolo di Sorana }\end{array}$ & Regional Management Office, Mostviertel \\
\hline $\begin{array}{l}\text { Affiliation and number } \\
\text { of interviewees }\end{array}$ & $\begin{array}{l}\text { Tuscany Region Office (3), Municipality of Pescia } \\
\text { (1), Ghiareto Association (1), Producers (4) }\end{array}$ & $\begin{array}{l}\text { Regional Management, Mostviertel (3), Association } \\
\text { of fruit producers, Mostviertel (1), Experts (2) }\end{array}$ \\
\hline Documents & $\begin{array}{l}\text { GI documents and protocols, reports from } \\
\text { Tuscany Region Office, Door Database }\end{array}$ & $\begin{array}{l}\text { Reports from Patent Office, GI documents and pro- } \\
\text { tocols, Door Database }\end{array}$ \\
\hline
\end{tabular}

Source: Own compilation.

of time and identify the main features of the contextual and institutional framework, which affect the magnitude of efforts, risks and benefits.

We selected two comparable, registered GI cases to guarantee data quality. This relied on the recall of interviewees. Considering the kind of data needed, access to information and availability of key-informants were also very relevant criteria for the case selection.

We selected the Sorana bean PGI (Fagiolo di Sorana) in Italy and Mostviertel perry PGI (Mostviertler Birnmost) in Austria (Table 1). They share similar value chain characteristics (few producers involved, and producers also process and market the products, mainly via short marketing channels), good product reputation and strong links to the territory. In both cases, producers registered a PGI according to EU legislation, and in both cases the whole supply chain (production and processing and preparation) is located in the delimited territory (even if according to EU regulation, a PGI can be granted also to products even when only one stage of the production process takes place in the indicated territory).

After analysing value chain characteristics, we collected data from 15 diverse supply chain actors (Table 1). The qualitative interviews (e.g., for understanding the PGI registration process, including open questions on benefits and risks), the structured interviews (e.g., for assessing the time effort of individuals involved, to rank risks and benefits derived from literature) and document analyses (e.g., for grasping the Product Specification and national GI regulations) took place from October 2013 through May 2014. Qualitative interviews were transcribed, coded and analyzed based on the IAD framework.

For estimating collective efforts, we asked interviewees to identify tasks along the four work packages of the PGI registration process:

- conception of and consensus on starting the GI registration process (e.g., main efforts involved in time invested in meetings by GI enterprises and related GI actors);

- agreement and drafting of the Product Specification (e.g., efforts needed for scientific trials to demonstrate the link between product and territory);
- national (and regional) phase of the GI registration process (formal procedures); and

- EU phase of the GI registration following the GI regulation.

We asked for the number of actors involved and time efforts spent on each task. We included efforts borne by the community of stakeholders in the GI territory, including producers' and/or processors' organizations and semipublic organizations acting at sub-national level (regions, provinces, municipalities, and/or development agencies). We did not include the efforts of national and EU authorities (e.g., national governments, EU Commission), as they are located outside of the GI territory.

Although we pursued an in-depth work, an evaluation of efforts based on a recall-approach remains a rough estimation (Mettepenningen and Van Huylenbroeck, 2009). Regarding data quality, producers documenting time and monetary efforts in real time throughout the whole registration processes would be a methodological proxy. This therefore required a substantial commitment from a large number of stakeholders involved in the registration process that lasts several years. Thus, empirical analyses of transaction costs are still a challenge (Wang, 2003; Mettepenningen and Van Huylenbroeck, 2009). However, multiple methods, cross-case triangulation as well as reflective loops (e.g., discussion of results with experts and interviewees) support the validity of the comparative analysis.

Furthermore, we asked interviewees to identify perceived risks and benefits at the time of the GI registration. We conducted the interviews in two steps. The first step was open. In the second step, we established risks and benefits according to predefined answer categories derived from literature. Interviewees answered using a five-point Likert scale $(1=$ strongly disagree to $5=$ strongly agree). According to Barjolle et al. (2009), this method can support the analysis of GI effects. Since both GIs were registered some time ago, we also consulted archives and documents to support the memory work of the interviewees. Data collection was followed by a qualitative text analysis (Patton, 2002), in which we triangulated the results from the interviews and document analyses to enhance the validity of results. 


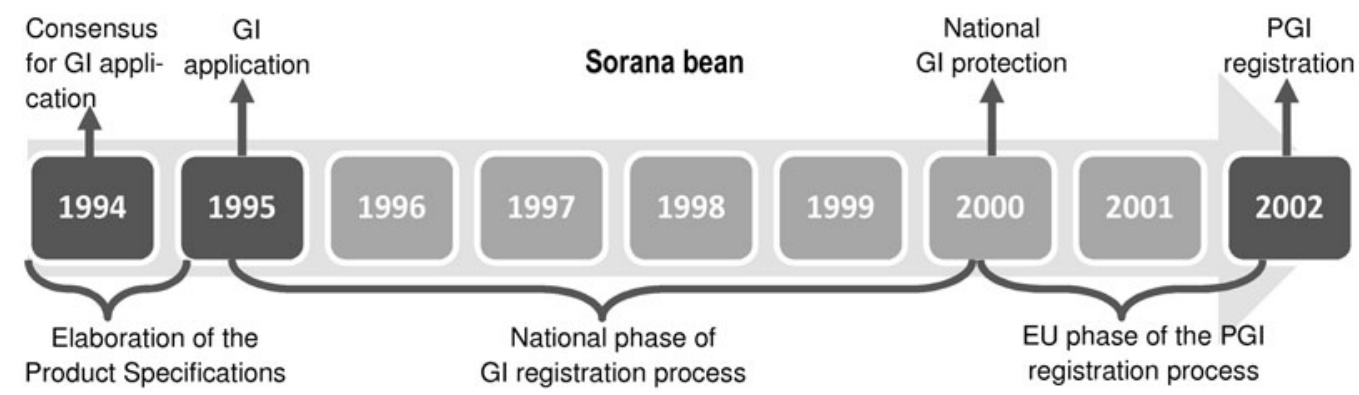

Figure 1. Timeframe for the Sorana bean GI registration.

\section{Results: analysis of registration processes, transaction efforts, risks and benefits}

For each case study, we first portray the contextual and institutional situation according to the IAD framework (territorial link to the product, attributes of the community, rules in use, action arena and outcome) and then present the collective efforts, risks and benefits.

\section{Sorana bean}

Contextual and institutional situation. The link between product and territory is strong. The bean cultivated today belongs to the Phaseolus vulgaris L. species. The seed is obtained from the plants that have been on site for many generations and have thus developed an ecotype that is perfectly adapted to the local environment, the climate and the characteristics of local soils. The production of the Sorana bean is located in the municipal area of Pescia in the district of Pistoia (Tuscany), a valley with pedological characteristics that impede the adoption of modern production techniques. The PGI area covers around 660 hectares, from the banks of the Pescia di Pontito creek (Ghiareto) to the uplands (Poggio). The local community is identified with the Sorana bean, but it is also well known in Tuscany and marketed on some niche channels. Consumers pay a price $6 / 7$ times higher than for a standard bean, which prompted the rise of a large amount of imitations. For the few big specialized farms, the Sorana bean accounts for a high percentage of total income, but it has minor economic relevance for many diversified small producers.

As for the attributes of the community, the few bean producers that exist are generally non-specialized, and some of them are retired or undertaking other working activities. The Associazione dei piccoli produttori del Fagiolo di Sorana Il Ghiareto ONLUS, founded in 1994, was responsible for the PGI application and now represents producers in the lowlands, who achieve higher quality (e.g., by developing promotional initiatives).

Regarding the rules in use, the good reputation of the Sorana bean coupled with unclear and missing rules on the use of its name brought problems of misuse and abuse. Following the approval of EU Council regulation 2081/92, Sorana bean producers started considering a PGI application. The small number and physical proximity of producers favored a direct, informal interaction, particularly in the lowlands.

In the action arena, some conflicts emerged between Poggio and Ghiareto producers due to the higher average production per hectare in Poggio and consequently different production costs, which allowed Poggio producers to sell their product at a lower price. During GI registration, the Municipality of Pescia coordinated the scientific research, involved producers in the design of the Product Specification and facilitated the achievement of an agreement. The close relationships between producers due to the very small size of the GI area and the low number of actors facilitated the registration process and recognition in 2002 (Fig. 1). These relationships supported the achievement of a common GI strategy.

As an outcome of the GI process, producers agreed on the Product Specification. Producers finally decided to extend the PGI production area to the entire Sorana valley (both Poggio and Ghiareto). The Municipality of Pescia and regional authorities supported this solution, given the narrowness of the area and the limited amount of production. Producers can add special mentions on the label when beans are from the most reputed Ghiareto sub-area. The extension of the production area to other historically less traditional areas, like Poggio, has strengthened the quantity produced, the visibility of Sorana bean in the market and the possibility to carry out collective promotional activities. The PGI production area however remains very small, showing pedological characteristics that impede the adoption of modern farming techniques. Other important points stated by the Product Specification are the ban on using chemical herbicides, a relatively low maximum yield per hectare (20 quintals) and an exact description of product characteristics as well as permitted harvesting methods. All these specific elements, guaranteed by the PGI scheme, give a strong identity to the product and, consequently, increase Sorana bean's reputation and recognizability among consumers, thus justifying the high-resale price on the market. 
Table 2. Efforts and number of persons involved in the Sorana bean PGI registration.

\begin{tabular}{lccc}
\hline Work packages & Years & $\begin{array}{l}\text { Effort }^{1} \text { in } \\
\text { person years }\end{array}$ & $\begin{array}{l}\text { Number of } \\
\text { Eersons }\end{array}$ \\
\hline I Conception of and consensus on the GI strategy & 1994 & 1.23 & 66.2 \\
II Agreement and drafting of the Product Specifications & $1994-1995$ & 0.34 & 18.3 \\
III National (and regional) phase of the GI registration process & $1995-2000$ & 0.28 & 15.0 \\
IV EU phase of the GI registration & $2000-2002$ & 0.01 & 0.5 \\
Sum & 8 & 1.86 & 100 \\
\hline
\end{tabular}

1 The time effort was estimated as person years ( 7.5 working hours day ${ }^{-1}, 220$ working days year $^{-1}$ ).

2 Not possible to sum up because of overlap/double counting between work packages.

Source: Own primary data.

Table 3. Sorana Bean-risks until registration as perceived by interviewees.

\begin{tabular}{|c|c|c|c|}
\hline Risks (shortened and translated statements from Italian and German questionnaires with scores $\geq 2$ ) & Score & $\begin{array}{l}\text { Standard } \\
\text { deviation }\end{array}$ & $\begin{array}{l}\text { Coefficient of } \\
\text { variation }(\%)\end{array}$ \\
\hline Difficulties in reaching consensus on the definition of the territorial area & 3.9 & 0.33 & 8,53 \\
\hline $\begin{array}{l}\text { Difficulties in reaching consensus on the Product Specification about process and/or product } \\
\text { quality }\end{array}$ & 3.0 & 0.87 & 28,87 \\
\hline Increased frictions between actors due to debate & 2.9 & 0.60 & 20,85 \\
\hline $\begin{array}{l}\text { Lack of knowledge of the legal situation as well as the inadequate experience of involved } \\
\text { organizations }\end{array}$ & 2.8 & 0.97 & 35,21 \\
\hline Lack of involvement of all actor groups (due to poor level of information, poor empowerment) & 2.6 & 0.79 & 30,75 \\
\hline The long and tedious GI registration process & 2.4 & 0.70 & 29,30 \\
\hline The debate about inclusion of additional geographical mentions (sub-designations) & 2.3 & 0.43 & 19,25 \\
\hline The involvement of public administrations due to their influence & 2.1 & 0.33 & 15,56 \\
\hline The potential rejection or failure of the GI application & 2.0 & 0.50 & 25,00 \\
\hline The elaboration of the Product Specification (e.g., scientific analyses) as a financial challenge & 2.0 & 0.50 & 25,00 \\
\hline
\end{tabular}

The score is the average level of agreement expressed by interviewees on a five-point scale from $1=$ strongly disagree to $5=$ strongly agree; pre-defined statements with case specific statements and specifications (in brackets) added from the interviewees.

Efforts, risks and benefits. Efforts made to register the Sorana bean PGI were considerable, when the small number of producers involved and low quantities produced are taken into account, in particular at the time the process started. According to the registration process (Table 2), the first work package demanded the highest effort $(66.2 \%$, in absolute terms 1.23 person years) due to the discussion needed for establishing the boundaries of the GI area and the rules for producers to take part in the GI process. The second work package took place from 1994 to 1995 and included diverse types of actors, such as producers, members of local government, local universities and research institutes. The Municipality of Pescia coordinated the activities for the design of the Product Specification. The second work package represented $18.3 \%$ of the total efforts, followed by the national (and regional) phase of the GI registration process. Although the effort in absolute terms was low ( 0.28 person years), it demanded about 5 years because of adjustments of the Product Specification and a delay of the national authorities due to bureaucratic reasons. During this second work package, the public consultation also took place in the area of production (mandatory according to Italian procedures of national implementation of the EU GI regulation) aimed at informing all stakeholders and to giving them the opportunity to debate (and to oppose to) the proposed Product Specification. Finally, in 2002 the Sorana bean PGI was registered. The EU phase of the GI registration took approximately 2 years and was the lowest effort in absolute $(0.01)$ and percentage terms $(0.5 \%)$. Not all producers actively took part in the formal GI process, as some producers are very small and/or hobby producers. However, the strong territorial contiguity and social interactions facilitated the circulation of information and informal communication of producers.

Before registration, interviewees perceived the main risks as the difficulty in reaching consensus between producers located in Ghiareto and Poggio due to diverging ideas about product quality and the delimitation of the production area (Table 3). Initially, Ghiareto producers did not approve inclusion of the Poggio area in the PGI boundaries due to Poggio's slightly diverging product characteristics. After registration, the main risks still entailed 
Table 4. Sorana bean-benefits until registration as perceived by interviewees.

Benefits (shortened and translated statements from Italian and German questionnaires with scores $\geq 2$ )

\begin{tabular}{|c|c|c|}
\hline Score & $\begin{array}{l}\text { Standard } \\
\text { deviation }\end{array}$ & $\begin{array}{l}\text { Coefficient of } \\
\text { variation (\%) }\end{array}$ \\
\hline
\end{tabular}

Improved pride of local GI enterprises with regards to the product

Increased motivation to produce better quality

Broader acceptance of common quality standards

Producers' deeper knowledge and awareness of product characteristics

External actors' (Italian and foreign) deeper knowledge and awareness of product characteristics Improved relations between private (enterprises) and public actors

Improved horizontal integration between producers

Improved vertical integration between producers and other supply chain actors (e.g., mass retailers)

$\begin{array}{lll}4.3 & 0.48 & 11.07 \\ 4.0 & 0.50 & 12.50 \\ 4.0 & 0.50 & 12.50 \\ 3.8 & 0.66 & 17.64 \\ 3.8 & 0.66 & 17.64 \\ 3.6 & 0.48 & 13.36 \\ 2.8 & 0.83 & 30.15 \\ 2.3 & 0.43 & 19.25\end{array}$

The score is the average level of agreement expressed by interviewees on a five-point scale from $1=$ strongly disagree to $5=$ strongly agree; pre-defined statements with case specific statements and specifications (in brackets) added from the interviewees.

difficulties in reaching consensus on how to control the PGI (e.g., due to the perceived low level of market controls of Sorana bean by public authority). The lack of knowledge about the legal framework and the information asymmetry among different producers categories were also perceived as relevant risks.

In terms of benefits, interviewees pointed out that, despite conflicts, the registration process facilitated cooperation between producers to achieve a common aim. Moreover, the GI process fostered the motivation to produce high-quality beans and increased the local pride of producers. Interviewees stated that the PGI registration process (news about the requested registration were reported frequently by media, from local newspapers to national TV) boosted the reputation of Sorana bean, favoring its direct marketing. Traceability and quality control enhanced product quality on the final market and opened up the access to new markets and marketing channels (Table 4).

The use of the Sorana bean PGI. From a total number of 40 bean producers in Sorana valley, about 22 actually use the GI label. The other mainly non-professional producers do not really need the GI certification, as many of them sell small quantities of beans to friends and relatives. Today's production is characterized by very low quantities and high-sale prices ( 22 euro $\mathrm{kg}^{-1}$ on average, compared with 3-4 euro $\mathrm{kg}^{-1}$ for conventional beans). Sorana beans are generally sold through direct marketing. Tuscany is the prevalent consumption market, although a small share of beans is sold to restaurants and agrifood shops in Northern Italy. The PGI certified production has grown from 57 quintals of certified beans in 2004 (first year of PGI implementation) up to 76 quintals in 2012, following a growth of surfaces (4.78 ha in 2004 to 5.22 ha in 2012 and 5.21 ha in 2013). Most production is carried out by small farms often managed by non-professional producers (retired, hobby, or part-time). The number of producers who use the PGI has slightly grown over the years but still remains very small (15 in 2004 and 22 in 2013). In addition, both supply chain actors and the whole territory benefited from Sorana bean's reputation gained through the PGI registration. In fact, the PGI supported the survival of agriculture in this area and revitalized the marginalized territory of the Sorana valley (Belletti et al., 2014) by facilitating the valorization of other products, such as local extra-virgin olive oil, or by promoting rural tourism (restaurants offering special bean menus and agro-tourism).

\section{Mostviertel perry}

Contextual and institutional analysis. Perry is produced by cask fermentation of pear juice obtained from pressing. 'Mostviertel' (Perry-Quarter) is the traditional geographical and administrative term for the south-eastern part of the province of Lower Austria. The first denomination of perry dates back to the year 1240 (Sommer et al., 2012). Since then, it has become integral to regional identity and economy. Perry lost its reputation after the Second World War and was replaced by beer and wine; nevertheless, a perry revival has been observed since the 1990s (Sommer et al., 2012). Nowadays, in addition to on-farm sales, several culinary and touristic events promote perry. However, perry producers usually depend on other sources of income. Approximately 20\% of the production is classified as high-quality perry and obtains premium prices, which can be 10 times the normal price.

The analysis of the attributes of the community shows that approximately 250 producers yield two million liters per year ( $2 / 3$ perry and $1 / 3$ cider). These producers have their own individual brands and marketing strategies. In total 150 producers are gathered under the Association of Fruit Producers from Mostviertel, which was founded in 1998 and is closely linked to the Chamber of Agriculture. Producers individually cultivate, harvest, process and directly market $90 \%$ of the perry to consumers within a distance of $40 \mathrm{~km}$. Although producers are gathered in the association, horizontal integration is weak. The GI registration process was initiated by the 


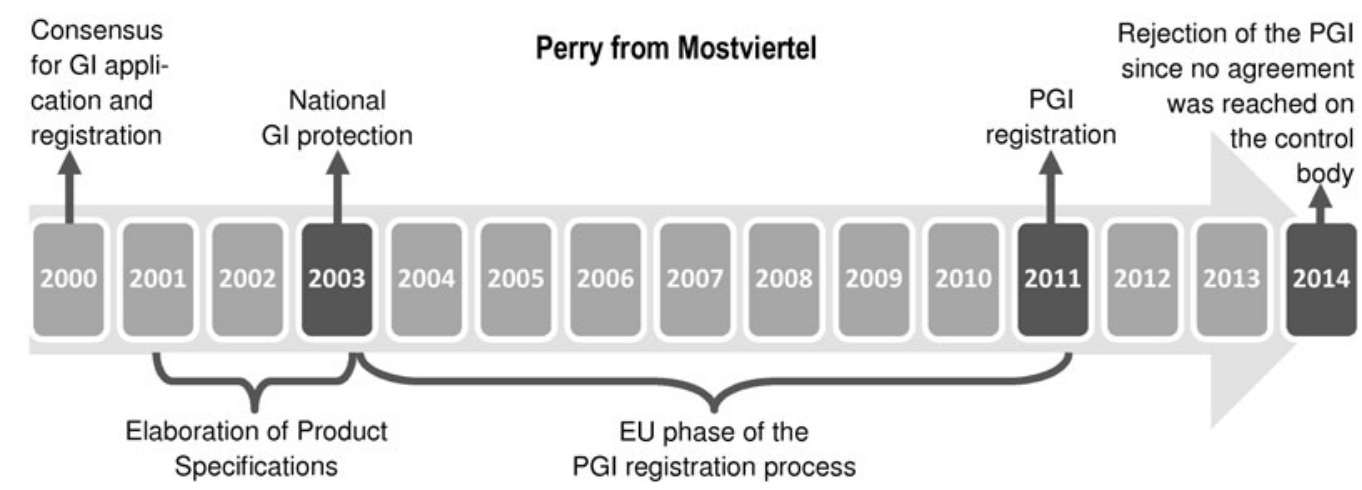

Figure 2. Timeframe for the Mostviertel perry GI registration.

Table 5. Efforts and number of persons involved in the Mostviertel perry PGI registration.

\begin{tabular}{|c|c|c|c|c|}
\hline Work packages & Years & $\begin{array}{l}\text { Effort }^{1} \text { in } \\
\text { person years }\end{array}$ & Effort in $(\%)$ & $\begin{array}{l}\text { Number of } \\
\text { persons }\end{array}$ \\
\hline I Conception of and consensus on the GI strategy & 2000 & 0.04 & 11.4 & 55 \\
\hline II Agreement and drafting of the Product Specifications & $2001-2003$ & 0.17 & 48.6 & 23 \\
\hline III National (and regional) phase of the GI registration process & 2003 & 0.01 & 2.9 & 21 \\
\hline IV EU phase of the GI registration & 2003-2011 & 0.13 & 37.1 & 22 \\
\hline Sum & 11 & 0.35 & 100 & $\left({ }^{2}\right)$ \\
\hline
\end{tabular}

1 The time effort was estimated as person years ( 7.5 working hours day ${ }^{-1}, 220$ working days year $^{-1}$ ).

2 Not possible to sum up because of overlap/double counting between work packages.

Source: Own primary data.

Regional Management Office in Mostviertel in close collaboration with the Association of Fruit Producers from Mostviertel.

As for the rules in use, the study pointed out that prior to the GI registration process, perry production was regulated by quality standards of Lower Austria and the Austrian Wine Law. Right from the beginning, producers were sceptical about new, additional regulations. Therefore, they adapted already existing quality regulations. Producers decided to protect the name 'Mostviertler Birnmost' after they realized that a German company was using that name on its homepage. Producers also looked for a common and consistent marketing strategy to differentiate their perry from Upper Austria.

The characterization of the action arena allowed identifying the actors that played a role along the GI registration process. After consulting the Austrian Patent Office, the Regional Management Office started and drove the GI registration process. In a board meeting at the end of 2000, the Association of Fruit Producers from Mostviertel on behalf of their members agreed to start the GI registration process (Fig. 2). Overall, there was little collective action among producers during the process. The Chamber of Agriculture located in Lower Austria provided external support regarding horizontal integration, quality management and marketing, but it had little previous GI experience.
The main outcome of the GI registration process was the Product Specification. The process allowed perry producers to become more aware about the product, quality standards and their regional identity. According to the Product Specification, only pears of 59 varieties typically cultivated in Mostviertel can be used to produce Mostviertel perry and approximately $2 \mathrm{~kg}$ of fruit are required for 1 liter of perry. As producers generally only use the fruit from their own trees, it is easy to relate the volume of perry to the yield of a farm tree by means of a plausibility test. If producers buy perry pears, they must ensure traceability by means of delivery notes.

Efforts, benefits and risks. Work package I formally started with the decision of the board of the Association of Fruit Producers from Mostviertel to initiate the GI process, after it interacted with Regional Management Office and the Austrian Patent Office. The approximately 55 members of the Association of Fruit Producers from Mostviertel were not actively involved in the debate but were informed about the board's decision. Thus, the estimated effort of 0.04 person years (Table 5) was much lower than in the Sorana bean case. The efforts for the second work package were higher, as most of the registration efforts $(46 \%)$ focused on preparing the Product Specification. Although already existing information and quality standards were used and adapted, the Regional Management Office hired an expert to 
Table 6. Mostviertel perry—risks until registration as perceived by interviewees.

\begin{tabular}{lccc}
\hline Risks (shortened and translated statements from Italian and German questionnaires with scores $\geq 2$ ) & Score & $\begin{array}{c}\text { Standard } \\
\text { deviation }\end{array}$ & $\begin{array}{c}\text { Coefficient of } \\
\text { variation (\%) }\end{array}$ \\
\hline Long and tedious GI registration process & 5.0 & 0.00 & 0.00 \\
Complex GI concept (which decreased participation of producers) & 4.3 & 0.47 & 10.88 \\
Difficulties in reaching consensus on the Product Specification about process and/or product & 3.7 & 1.25 & 34.02 \\
$\quad$ quality & 4.0 & 0.82 & 20.41 \\
Lack of knowledge on legal situation as well as the inadequate experience of the involved & & & \\
$\quad$ organizations & 3.0 & 1.63 & 54.43 \\
Not all actor groups were involved (strategic reasons) & 3.0 & 0.82 & 27.22 \\
GI debate increased frictions between actors & 2.7 & 1.70 & 63.74 \\
Producers' low acceptance of an external control system (already before GI registration) & 2.7 & 1.70 & 63.74 \\
Competition among producers & 2.3 & 0.47 & 20.20 \\
Unclear competence and/or the amount of public authorities involved & 2.0 & 1.41 & 70.71 \\
Difficulties in reaching consensus on the definition of the territorial area & &
\end{tabular}

The score is the average level of agreement expressed by interviewees on a five-point scale from $1=$ strongly disagree to $5=$ strongly agree; pre-defined statements with case specific statements and specifications (in brackets) added from the interviewees.

Table 7. Mostviertel perry-benefits until registration as perceived by interviewees.

\begin{tabular}{lrr}
\hline $\begin{array}{l}\text { Benefits (shortened and translated statements from Italian and German questionnaires with scores } \\
\mathbf{2} \text { ) }\end{array}$ & $\begin{array}{l}\text { Standard } \\
\text { Score } \\
\text { deviation }\end{array}$ & $\begin{array}{c}\text { Coefficient of } \\
\text { variation (\%) }\end{array}$ \\
\hline Better product specification and product description & 4.0 & 0.00 \\
Motivation to debate the future of region and its development & 4.0 & 0.00 \\
An opportunity to increase perry sales (e.g., out of the region) & 3.7 & 0.00 \\
Improved horizontal integration between producers & 3.0 & 0.00 \\
Improved vertical integration between producers and other supply chain actors (e.g., gastronomy) & 2.0 & 0.00 \\
\hline
\end{tabular}

The score is the average level of agreement expressed by interviewees on a five-point scale from $1=$ Strongly disagree to $5=$ Strongly agree; pre-defined statements with case specific statements and specifications (in brackets) added from the interviewees.

scientifically analyze the pears. The time effort for the third work package was minimal, since the GI application was handed over to the Patent Office staff. There was little need for further interaction, as the Patent Office had been involved from the beginning of the GI process. This phase only needed $2.9 \%$ of the total registration efforts. The period for the fourth work package was the longest (from 2003 to 2011), since the content of the Product Specification did not comply with EU stipulations. After national registration in 2003, the EU PGI registration was obtained in 2011, the EU phase of the GI registration demanded $37.1 \%$ of the total efforts.

In terms of risks (Table 6), interviewees were already aware of the challenge of finding an agreement on an external control body, although the withdrawal of the PGI was only decided after the interviews. Apparently, many producers were not truly aware of what the GI meant for them. It was only after debates and the negotiations after registration that several producers realized that they could have better protected the pears instead of the perry or that they could protect the name via wine regulations.

Considering the benefits, the interviewees perceived that 'the marketing of the region under one roof, as collective marketing' was a benefit. Table 7 shows the ranked benefits stated by the interviewees.

The use of the Mostviertler perry PGI. After PGI registration, producers were unable to agree on a control system. As a result, in a meeting in 2014, the board of the Association of Fruit Producers from Mostviertel decided not to use the PGI and formally withdrew from the EU protection. Producers have never used the PGI, since the majority of them-particularly the smaller ones with lower quality and farm sales - did not agree on a control body, additional controls and certification fees. Nonetheless during and after the PGI process, some other collective marketing strategies, such as Genussregion (delicacy region), were successfully developed in the region. Producers located in the Genussregion Mostviertel continued selling their perry predominantly with their own individual brands as before. Unlike the Sorana bean, the Mostviertel perry producers, after a long GI registration process, decided not to use the PGI, as they were not able to agree on an external control body. In the Sorana case, the certification body did not play a role in the registration process, although in general it may happen that the certification body 
already supported the ex-ante phase. Another particularity is that in the perry case local authorities were not involved during the GI registration process, but an expert was recruited to scientifically analyze the pears.

\section{Discussion}

Both GI registrations were formally successful and share similar contexts (e.g., small production areas, products embedded in the region, heterogeneous producers both non-professional and professional, short supply chains). However, the action arenas show very contrasting patterns of interaction and involvement among producers, semi-public organizations and research centers that result in diverging transaction efforts, risks and benefits as already illustrated by Enengel et al. (2014) for the example of landscape co-management. A synthesis of both GI registration processes (Sorana bean and Mostviertel perry) is shown in Table 8.

The Sorana bean producers and associated local actors put much more effort in meetings, information gathering and negotiation for the conception of and consensus on the GI strategy (1.23 person years). In the perry case, this first phase was limited to 0.04 person years and restricted to a board meeting and subsequent information of producers. This early phase in the Sorana bean case was accompanied by many difficulties, conflictual debates, which contrasted the smooth consensus in Mostviertel. In addition, defining the Product Specification needed twice as much effort for Sorana bean ( 0.34 person years) as for perry (0.17). Many of the associated conflicts in the Sorana bean territory focused on quality (quality standards, territories of lower qualities to be included or not), whereas this was not an issue of major debate in Mostviertel, as producers agreed to stick to existing quality standards.

The difference in the PGI use however is remarkable. While many professional and semi-professional Sorana bean producers sell their beans with the PGI label, perry producers are still selling their product under diverse individual farm brands without the GI label. Perry producers even decided to withdraw from the PGI protection, allowing them to use the geographical name without having to stick to the PGI rules.

We argue that these mixed outcomes arise from the diverging scope of collective action and participation of the community of producers in the early phase of the GI registration process. The Sorana bean case, in comparison with the Mostviertel perry, showed the ability of the producers to constitute themselves in a group and to discuss all issues related to the GI registration strategy. Our findings confirm that intensified interaction of producers results in higher trust and in a better appropriation of the meaning of GI protection. The propensity to collaborate with someone depends on the degree of trust previously deposited in that person (Torre, 2006). Thus, as the relationship advances, participants obtain new information, for instance regarding the integrity of the partner, what promotes the possibility to make judgments.

National institutional settings of the EU regulations on GIs also played a role. In Italy, for instance, the public consultation of stakeholders in the area of production is mandatory. This improves the information of all stakeholders', but also increases the probability of time-demanding debates and oppositions before registration. The Mostviertel case, however, indicates that it might be useful to have these debates before, rather than after the registration.

The Sorana bean case illustrates substantial collective efforts. Despite the diversity of producers and different reputation of the two production sub-areas implying a low level of trust, intensive interaction in the first two phases of the registration process facilitated consensus on the GI strategy. The individual producers were actively and directly involved in reaching consensus on the common quality standards needed to obtain the PGI recognition. This happened both in formal consultations and in informal ways, thanks to strong territorial proximity and exhaustive social interactions. Menard (2004) states that inter-firm arrangements imply the need for considerable amounts of time and resources to collectively find agreements on adjustments needed in order to reach agreements and solve conflicts. Thus, beans producers were able to elaborate horizontal arrangements. On the contrary, the perry case shows that the majority of producers, whose perry is marketed locally and individually, were not involved in the first two important phases of the registration process. The ones who took the lead along the GI process together with the Regional Management from Mostviertel might have not represented the interests of the majority but rather those of few high-end quality producers looking for international fairs and markets.

According to Arnstein (1969), who distinguishes information, consultation and co-decision making as different forms of participation, the Sorana bean case represents a situation with a high degree of consultation and co-decision making, while most perry producers were merely informed of decisions made by the representative body. In the Sorana bean case, exhaustive discussions and major conflicts and negotiations ended in the broad accepted of common agreements and decision making that inherently implied a shared understanding of GIs, trust building and integration of producers. In contrast, the majority of perry producers only fully grasped the meaning of the GI after it was granted, when the majority of them realized that they do not want formalized control but just wanted to sell their perry with individual farm labels as they had before GI registration. This confirms Randall's (1981) argument that transaction costs are not 'money down a rat hole' and is in line with previous empirical transaction studies on landscape co-management showing positive correlations between individual time efforts for and benefits of participation (Enengel et al., 2014). In the perry case, major risks and challenges were 
Table 8. Synthesis of both registration processes.

\begin{tabular}{|c|c|c|c|c|c|c|c|c|}
\hline \multirow[b]{2}{*}{ Work packages } & \multicolumn{4}{|l|}{ Sorana bean } & \multicolumn{4}{|c|}{ Mostviertel perry } \\
\hline & $\begin{array}{l}\text { Effort }^{1} \text { in } \\
\text { person years }\end{array}$ & Effort in $(\%)$ & $\begin{array}{l}\text { Number of } \\
\text { persons }\end{array}$ & Years & $\begin{array}{l}\text { Effort }^{1} \text { in } \\
\text { person years }\end{array}$ & $\begin{array}{l}\text { Effort in } \\
(\%)\end{array}$ & $\begin{array}{l}\text { Number of } \\
\text { persons }\end{array}$ & Years \\
\hline I Conception of and consensus on the GI strategy & 1.23 & 66.2 & 21 & 1994 & 0.04 & 11.4 & 55 & 2000 \\
\hline II Agreement and drafting of the Product Specifications & 0.34 & 18.3 & 15 & 1994-1995 & 0.17 & 48.6 & 23 & $2001-2003$ \\
\hline III National (and regional) phase of the GI registration process & 0.28 & 15.0 & 40 & $1995-2000$ & 0.01 & 2.9 & 21 & 2003 \\
\hline IV EU phase of the GI registration & 0.01 & 0.5 & 1 & $2000-2002$ & 0.13 & 37.1 & 22 & $2003-2011$ \\
\hline Total & 1.86 & 100.0 & $\left({ }^{2}\right)$ & 8 & 0.35 & 100.0 & $\left({ }^{2}\right)$ & 11 \\
\hline
\end{tabular}

Contextual and institutional structure

Link between product and territory

The seed is obtained from the plants that have been on site

The first denomination of perry dates back to the year for many generations, thus enabling an ecotype perfectly

$$
\text { adapted to the local environment }
$$

Attributes of the producers

Motivation to protect the product

Action arena

Outcome

\begin{abstract}
Mainly non-specialized farmers, some of them retired or undertaking other working activities as well as specialized

$$
\text { farmers }
$$
\end{abstract}

Misuse and abuse of the (unprotected) Sorana bean GI

The association of small bean producers was established at the beginning of the GI process. Conflicts between

Poggio and Ghiareto producers due to the higher average production per hectare in Poggio and associated quality discrepancies. The Municipality of Pescia coordinated scientific research and served as facilitator for reaching agreements

Producers implement common quality standards and the definition of Product Specification. Ghiareto producers are allowed to add special mentions. There is an increase of quantity produced and visibility of the Sorana bean

Only few farmers produce high-quality perry, most of them produce average or low quality

Misuse of the name 'Mostviertler Birnmost' by a German company, and the need for a common marketing strategy

The GI registration process was initiated by the Regional Management Mostviertel in collaboration with the already existing Association of the Fruit Producers Mostviertel, which acted on behalf of their members. The registration was successfully concluded without major conflicts

Several producers were not actively involved in the debate to understand what the protection of GIs implies. After the PGI was obtained, conflicts about the control body resulted in a withdrawal of the GI protection. Producers use other strategies to jointly market their perry (e.g., Genussregion)

${ }_{1}$ The time effort was estimated as person years ( 7.5 working hours day ${ }^{-1}, 220$ working days year $\left.^{-1}\right)$.

2 Not possible to sum up because of overlap/double counting between work packages.

Source: Own primary data. 
postponed, as there were not truly collective debates and justifications for starting the GI process in the initial phase. This confirms Hanna's (1994, 1995) assertion that less collective efforts invested and realized in the ex-ante phase has to be spent afterwards. Debates or conflicts avoided during the early phases of the perry registration were observed in the implementation phase.

Nonetheless, we assume that the efforts for a collective GI process will not only depend on the degree and form of participation but also on group size and heterogeneity of supply chain actors (e.g., how many and what kind of producers are involved-specialists, artisans). Both cases present two small universes of heterogeneous producers, implying the appearance of risks, such as conflicting interests (Dentoni et al., 2012; Crespo et al., 2014; Dervillé and Allaire, 2014). However, strong interactions among divergent types of producers in forms of debates, collective decision making, knowledge sharing and communication in itself resulted in a more beneficial ex-post situation in the Sorana bean case due to the social cohesion that was developed. Promoting the authority of individuals to formulate their own rules might result in social processes that allow the evolution of social norms and therefore might boost the probability that individuals solve their collective action problems (Ostrom, 2000).

Both GI registration processes were initiated and driven by small groups of producers in cooperation with (regional or national) authorities. In the Austrian case, the Regional Management Office initiated the process and implemented it together with the Association of Fruit Producers from Mostviertel, while in the Italian case the GI registration process was led by some producers with the support of the local municipality (Pescia). In both cases, the overall duration of the PGI registration was long, due to the lack of knowledge for designing the Product Specification, limited GI experience of the producers and national authorities in charge of the GI registration process. The institutional environment of self-organization (established rules of producer organizations but also informal customs of collaboration) (Tregear et al., 2007; Markelova et al., 2009; Belletti and Marescotti, 2011; Belletti et al., 2015) and supportive organizations (e.g., public authorities) were more favorable in the Sorana bean case. Geographical proximity can activate collective action and the institutional networking of actors (Filippi and Torre, 2003). Previous collective investments on the product (such as research to technically characterize the product made by local universities) and informal support from public bodies (such as consulting, mediation and moderation of group processes) facilitate applications even for small producer groups, which otherwise would be disadvantaged because of considerable fixed costs in relation to the small production volume and value. These fixed costs include costly technical analyses justifying the link between product and territory or consultancies in writing the Product Specification. In the Austrian case, support from the Chamber of Agriculture and the Patent
Office was limited, due to little GI experience in Austria, unclear competencies and limited personnel resources. The analysis shows that researchers and consultants can also act as third parties to reconcile diverse viewpoints and interests of heterogeneous producers. Neither of the two cases involved certification bodies in the elaboration of Product Specification, although they checked the producers' compliance with the Product Specification after registration. The support of facilitators or innovation brokers promote interaction and debate when pursuing the registration of GIs, similar to other innovative agricultural systems (Klerkx and Gildemacher, 2012).

\section{Conclusion}

Among the manifold strategies for product differentiation, GIs present an interesting opportunity for those products whose characteristics are strongly linked to the territory from which they originate. In order to protect and regulate GI use, producers have to self-organize and collaborate. As highlighted by our case studies, this interaction of heterogeneous supply chain actors, authorities and researchers can be conflict-laden, complex and time-demanding. Although interaction is costly in terms of time, our results suggest that the early and direct involvement of all conflicting interest groups pays off and can facilitate empowerment, trust and social cohesion, higher acceptance of common quality standards, colearning processes on product characteristics and a higher use of the GI label after registration. A supportive legal framework along with the support of public authorities can back up the community of producers not only in terms of technical aspects but also in a mediator when conflicts appear to be difficult to solve. As there seems to be a positive relationship between intensity and effectiveness of collective action and the likelihood of achieving broadly accepted standards and the social cohesion needed for the successful GI implementation, the question for future research is how to effectively organize the interaction among heterogeneous producer groups.

Acknowledgments. We gratefully acknowledge the funding provided by the Austrian National Bank (OeNB) for conducting this research. We kindly thank Elisa Barzini and Magdalena Pircher for conducting the interviews. We thank all interviewees, especially Angela Crescenzi, Luciano Zoppi, Stefano Barzagli, Giovanni Piscolla, Simona Toni, Giorgio Castiglione, Fabrizio Salvadorini, Mauro Carreri, Romano Dingacci, Rita Chelini, Alfio Marchini, Ota and Olma in Italy and Andreas Ennser, Karl Becker, and Gerald Weinhart in Austria for the efforts of providing data and recalling the PGI-registration processes. We also thank Christina Roder for proofreading the paper.

\section{References}

Allen, D.W. 1991. What are transactions costs? Research Law and Economics, 14:1-18. 
Arnstein, S.R. 1969. A ladder of citizen participation. Journal of the American Institute of Planners 35(4):216-224.

Babcock, B.A. and Clemens, R. 2004. Geographical Indications and Property Rights: Protecting Value-Added Agricultural Products. Publications 04-mbp7, Midwest Agribusiness, Trade Research and Information Center (MATRIC), Iowa State University, Ames, IA.

Bagal, M., Belletti, G., Marescotti, A., and Onori, G. 2013. Study on the potential of marketing of Kenyan Coffee as Geographical Indication. European Commission. Available at Web site http://ec.europa.eu/agriculture/external-studies/2013/ gis-acp-countries/case-study-coffee-kenya_en.pdf (verified 10 October 2014).

Barjolle, D. 2016. Geographical indications and protected designations of origin: intellectual property tools for rural development objectives. In D.S. Gangjee (ed.). Research Handbook on Intellectual Property and Geographical Indications. Edward Elgar Publishing, Cheltenham, UK. pp. $440-462$.

Barjolle, D. and Sylvander, B. 2000. Some Factors of Success for 'Origin Labelled Products' in Agri-food Supply Chains in Europe: Market, Internal Resources and Institutions. SRVA, Lausanne, Switzerland. INRA-UREQUA, Le Mans, France.

Barjolle, D., Paus, M., and Perret, A. 2009. Impact of geographical indications: a review of methods and empirical evidences. Presented at the International Association of Agricultural Economists Conference, Beijing, China, August 16-22.

Belletti, G. and Marescotti, A. 2011. Evaluating the effects of protecting geographical indications: scientific context and case studies. In G. Belletti, A. Deppeler, A. Marescotti, M. Paus, S. Réviron, H. Stamm, and E. Thévenod-Mottet (eds). The Effects of Protecting Geographical Indications. Ways and Means of their Evaluation. Publication no. 7 (07.11). Swiss Federal Institute of Intellectual Property, Berne. p. 31-121.

Belletti, G., Brazzini, A., and Marescotti, A. 2014. The effects of the legal protection geographical indications: PDO/PGI in Tuscany. In Proceedings of the 11th European International Farming System Association (IFSA) Symposium, Berlin, 1-4 April.

Belletti, G., Marescotti, A., and Touzard, J.M. 2015. Geographical indications, public goods and sustainable development: The roles of actors' strategies and public policies. World Development, in press.

Biénabe, E., Kirsten, J., and Bramley, C. 2011. Collective action dynamics and product reputation. In C. Bramley, E. Bienabe, and J. Kirsten (eds). Developing Geographical Indications in the South. Springer Netherlands, Dordrecht. p. 51-72.

Bowen, S. and Zapata, A. 2009. Geographical indications, terroir, and socioeconomic and ecological sustainability: The case of tequila. Journal of Rural Studies 25:108-119.

Casabianca, F., Sylvander, B., Noël, Y., Béranger, C., Coulon, J.B., and Roncin, F. 2005. Terroir et typicité: deux concepts-clés des appellations d'origine contrôlée. Essai de définitions scientifiques et opérationnelles. Communication pour le Symposium international de Programme Recherche Pour et Sur le Développement Régional (PSDR): Territoires et Enjeux du Développement Régional. Lyon, France; 9-11 March.

Coulet, T. 2012. Assessing the economic impact of GI protection. In M. Blakeney, T. Coulet, G. Mengistie, and M.T.
Mahop (eds). Extending the Protection of Geographical Indications Earthscan, Abingdon. p. 101-119.

Crespo, J., Requier-Desjardins, D., and Vicente, J. 2014. Why can collective action fail in local agri-food systems? A social network analysis of cheese producers in Acapulco, Mexico. Food Policy 46:165-77.

Dentoni, D., Menozzi, D., and Capelli, M.G. 2012. Group heterogeneity and cooperation on the geographical indication regulation: The case of the "Prosciutto di Parma" consortium. Food Policy 37(3):207-216.

Dervillé, M. and Allaire, G. 2014. Change of competition regime and regional innovative capacities: Evidence from dairy restructuring in France. Food Policy 49:347-360.

Enengel, B., Penker, M., Muhar, A., and Williams, R. 2011. Benefits, efforts and risks of participants in landscape comanagement: An analytical framework and results from two case studies in Austria. Journal of Environmental Management 92(4):1256-1267.

Enengel, B., Penker, M., and Muhar, A. 2014. Landscape co-management in Austria: The stakeholder's perspective on efforts, benefits and risks. Journal of Rural Studies 34:223-234.

Falconer, K. and Whitby, M. 1999. Administrative Costs in Agricultural Policies: The Case of the English Environmentally Sensitive Areas (ESAs). University of Newcastle, Centre for Rural Economy, Newcastle. Research Report.

Filippi, M. and Torre, A. 2003. Local organisations and institutions: How can geographical proximity be activated by collective projects? International Journal of Technology Management 26(2/3/4):386-400.

Galtier, F., Belletti, G., and Marescotti, A. 2013. Factors constraining building effective and fair geographical indications for coffee: Insights from a Dominican case study. Development Policy Review 31(5):597-615.

Giovannucci, D., Josling, T., Kerr, W., O'Connor, B., and Yeung, M.Y. 2009. Guide to Geographical Indications. Linking Products and Their Regions. Available at Web site www.intracen.org/WorkArea/DownloadAsset.aspx?id=37595 (verified 12 September 2014).

Giovannucci, D., Barham, E., and Pirog, R. 2010. Defining and marketing "local" foods: Geographical indications for US products. Journal of World Intellectual Property 13(2): 94-120.

Hanna, S.S. 1994. Co-management. In K.L. Gimbel (ed.). Limiting Access to Marine Fisheries: Keeping the Focus on Conservation. World Wildlife Fund and Center for Marine Conservation, Washington, DC. p. 233-234.

Hanna, S.S. 1995. Efficiencies of user participation in natural resources management. In S. Hanna and E. Munasinghe (eds). Property Rights in a Social and Ecological Context. Case Study and Design Application. The Beijer International Institute of Ecological Economics and the World Bank, Washington, DC. p. 59-67.

Hess, C. and Ostrom, E. 2007. Framework for analyzing the knowledge commons. In C. Hess and E. Ostrom (eds). Understanding Knowledge as a Commons: From Theory to Practice. MIT Press, Cambridge, MA. p. 41-82.

Ilbery, B. and Kneafsey, M. 2000. Registering regional specialty food and drink products in the United Kingdom: The case of PDOs and PGIs. Area 32:317-325.

Jena, P.R. and Grote, U. 2010. Changing institutions to protect regional heritage: A case for geographical indications in the 
Indian agrifood sector. Development Policy Review 28(2): 217-236.

Klerkx, L. and Gildemacher, P. 2012. The role of innovation brokers in agricultural innovation systems. In Agricultural Innovation Systems: An Investment Sourcebook. The World Bank, Washington, DC. p. 221-230.

Markelova, H., Meinzen-Dick, R., Hellin, J., and Dohrn, S. 2009. Collective action for smallholder market access. Food Policy 34:1-7.

McCann, L. and Easter, K.W. 1997. Transaction costs of policies to reduce agricultural phosphorus pollution in the Minnesota River. Land Economics 75(3):402-414.

McCann, L.B., Colby, K., Easter, W., Kasterine, A., and Kupera, K.V. 2005. Transaction cost measurement for evaluating environmental policies. Ecological Economics 52: 527-542.

Menard, C. 2004. The economics of hybrid organizations. Journal of Institutional and Theoretical Economics 160: 354-376.

Mettepenningen, E. and Van Huylenbroeck, G. 2009. Factors influencing private transaction costs related to agri-environmental schemes in Europe. In F. Brouwer and C. Martijn van der Heide (eds). Multifunctional Rural Land Management Economics and Policies. Earthscan, London. p. $145-168$.

North, D.C. 1990. Institutions, Institutional Change and Economic Performance. Cambridge University Press, Cambridge.

Ostrom, E. 1990. Governing the Commons: The Evolution of Institutions for Collective Action. Cambridge University Press, New York.

Ostrom, E. 2000. Collective action and the evolution of social norms. Journal of Economic Perspectives 14(3):137-158.

Ostrom, E. 2005. Understanding Institutional Diversity. Princeton University Press, Princeton, NJ.

Ostrom, E. and Polski, M. 1999. An Institutional Framework for Policy Analysis and Design. Workshop in Political Theory and Policy Analysis, Department of Political Science, Indiana University.

Ostrom, E., Gardner, R., and Walker, J. 1994. Rules, Games, and Common-pool Resources. University of Michigan Press, Michigan.

Patton, M.Q. 2002. Qualitative Research and Evaluation Methods. 3rd ed. Sage Publications, London.

Paus, M. and Reviron, S. 2010. Crystallisation of collective action in the emergence of a geographical indication system. In Proceedings of the 116th EAAE Seminar "Spatial Dynamics in Agrifood Systems: Implications for Sustainability and Consumer Welfare". Parma, Italy 27-30 October.

Penker, M. and Klemen, F. 2010. Transaction costs and transaction benefits associated with the process of PGI/PDO registration in Austria. In Proceedings of the 116th EAAE Seminar "Spatial Dynamics in Agrifood Systems: Implications for Sustainability and Consumer Welfare". Parma, Italy 27-30 October.

Poteete, A.R., Janssen, M.A., and Ostrom, E. 2010. Working Together: Collective Action, the Commons, and Multiple Methods in Practice. Princeton University Press, Princeton, NJ.
Quiñones-Ruiz, X.F., Belletti, B., Leitgeb, F., Marescotti, A., Penker, M., Samper-Gartner, L.F., and Scaramuzzi, S. 2014. Comparing registration efforts for Protected Geographical Indications in Austria, Colombia and Italy. Paper presented at 11th European IFSA Symposium "Farming systems facing global challenges: Capacities and strategies", Berlin (Germany), April 1-4, 2014.

Quiñones-Ruiz, X.F., Penker, M., Vogl, C.R., and SamperGartner, L.F. 2015. Can origin labels re-shape relationships along international supply chains? - The case of Café de Colombia. International Journal of the Commons 9(1): 416-439.

Randall, A. 1981. Resource Economics: An Economic Approach to Natural Resources and Environmental Policy. Grid Publishing, Colombus, Ohio.

Rangnekar, D. and Mukhopadhyay, P. 2016. Social gains from the GI for Feni: will market size or concentration dominate outcomes? In D.S. Gangjee (ed.). Research Handbook on Intellectual Property and Geographical Indications. Edward Elgar Publishing, Cheltenham, UK. pp. 463-483.

Reviron, S. and Chappuis, J.M. 2011. Geographical Indications: Collective organization and management. In E. Barham and B. Sylvander (eds). Labels of Origin for Food: Local Development, Global Recognition. CABI, Wallingford. p. $45-62$.

Sanz-Cañada, J. and Macías-Vázquez, A. 2005. Quality certification, institutions and innovation in local agro-food systems: Protected designations of origin of olive oil in Spain. Journal of Rural Studies 21(4):475-486.

Sidali, K.L. and Scaramuzzi, S. 2014. Group heterogeneity and cooperation in the governance of geographical indications. The case of Parmigiano Reggiano 'mountain product'. International Agricultural Policy 1:21-32.

Sommer, E., Höbaus, E., and Reinthaler, D. 2012. Mostviertler Birnmost g.g.A. - Registernummer 20. Available at Web site http://www.bmlfuw.gv.at/land/lebensmittel/trad-lebensmittel/getraenke/mostviertl_birnmost.htmlg.g.A. (verified 28 January 2015).

Torre, A. 2006. Collective action, governance structure and organizational trust in localized systems of production. The case of the AOC organization of small producers. Entrepreneurship and Regional Development 18(1):55-72.

Tregear, A., Arfini, F., Belletti, G., and Marescotti, A. 2007. Regional foods and rural development: The role of product qualification. Journal of Rural Studies 23(1):12-22.

Vandecandelaere, E., Arfini, F., Belletti, G., and Marescotti, A. 2009. Linking People, Places and Products. A Guide for Promoting Quality Linked to Geographical Origin and Sustainable Geographical Indications. Food and Agriculture Organization of the United Nations (FAO) and SINER-GI, Rome.

Wang, N. 2003. Measuring transaction costs: An incomplete survey. Ronald Coase Institute. Working Paper Series. Working Paper Number 2. Available at Web site https:/l www.coase.org/workingpapers/wp-2.pdf (verified 20 July 2014).

Winfree, J.A. and McCluskey, J.J. 2005. Collective reputation and quality. American Journal of Agricultural Economics 87(1):206-213. 